\title{
Peranan Persepsi Dukungan Sosial terhadap Kesejahteraan Subjektif di Sekolah pada Siswa Pondok Pesantren Modern
}

\author{
Hasna Thohiroh, Langgersari Elsari Novianti, Whisnu Yudiana \\ Fakultas Psikologi, Universitas Padjadjaran, Indonesia \\ e-mail:whisnu.yudiana@unpad.ac.id
}

\begin{abstract}
The purpose of this study is to examine the role of perceived social support from parents, friends, and teachers on subjective well-being in school and its correlation with school satisfaction and affect in school. This study uses a quantitative correlational method with a path analysis. Participants $(N=264)$ were students in classes seven and eight in the modern Islamic boarding junior high school in West Java. The results show that perceived social support from teachers and friends has a significant impact on subjective well-being in school, while perceived family support has not. Perceived friend support was significantly correlated with school satisfaction and affect in school; perceived social support from teachers significantly correlated with school satisfaction but not with affect in school.
\end{abstract}

Keywords: perceived social support, subjective well-being in school, modern Islamic boarding school

\begin{abstract}
Abstrak
Penelitian ini bermaksud untuk mengetahui peranan persepsi dukungan sosial dari orang tua, teman, dan guru terhadap kesejahteraan subjektif di sekolah, serta hubungan antara persepsi dukungan sosial dari ketiga sumber tersebut dengan dimensi school satisfaction dan affect in school. Penelitian ini menggunakan metode kuantitatif korelasional dengan pendekatan analisa jalur. Partisipan $(\mathrm{N}=264)$ merupakan siswa kelas tujuh dan delapan pada salah satu Pondok Pesantren Modern di Jawa Barat. Hasil penelitian menunjukkan bahwa persepsi dukungan sosial dari guru dan teman berperan secara signifikan terhadap kesejahteraan subjektif di sekolah, sementara persepsi dukungan sosial dari orang tua tidak berhubungan signifikan. Persepsi dukungan sosial teman berhubungan signifikan dengan dimensi school satisfaction dan affect in school; persepsi dukungan sosial dari guru berhubungan signifikan dengan school satisfaction tetapi tidak dengan affect in school.
\end{abstract}

Kata kunci: persepsi dukungan sosial, kesejahteraan subjektif di sekolah, pondok pesantren modern

\section{Pendahuluan}

Salah satu tempat yang penting bagi remaja untuk mempelajari berbagai macam pengetahuan adalah sekolah. Sekolah tidak hanya membantu pembelajaran akademik bagi remaja, namun menyediakan lingkungan sosial seperti teman sebaya dan sahabat yang akan memberikan pengaruh kuat bagi perkembangannya (Santrock, 2011). Sekolah merupakan salah satu domain spesifik yang paling penting dalam memfasilitasi perkembangan remaja dan kesejahteraan subjektif siswa secara global (Tian dkk., 2014). Oleh sebab itu, orang tua perlu selektif dalam memilih sekolah atau lembaga pendidikan formal untuk remaja.

Saat ini sekolah atau pendidikan formal berbasis agama seperti pesantren cukup banyak diminati masyarakat (Arsita dkk., 2016). Masyarakat beranggapan bahwa pesantren mampu menghasilkan manusia yang memiliki moralitas dan tingkat keimanan tinggi (Azizah \& Hidayati, 2015). Siswa yang mengikuti program pesantren atau yang biasa juga disebut dengan nama santri wajib untuk tinggal selama 24 jam di asrama (Pritaningrum \& Hendriani, 2013). Siswa 
yang mengikuti pendidikan di pesantren, juga tinggal di dalam pesantren. Para siswa diharuskan mentaati semua peraturan dan menghabiskan seluruh waktunya untuk tinggal di dalam pesantren. Karena itu, selain menjadi tempat tinggal yang menyenangkan bagi siswanya, pesantren diharapkan juga memberikan rasa nyaman dan aman (Azizah \& Hidayati, 2015).

Perasaan nyaman dan senang terjadi jika siswa memiliki penilaian yang positif terhadap sekolahnya. Penilaian siswa terhadap kehidupannya di sekolah dapat disebut sebagai kesejahteraan siswa di sekolah. Azizah dan Hidayati (2015) menjelaskan bahwa lingkungan sekolah yang kondusif memberikan dampak positif pada siswa sehingga siswa akan merasakan kesejahteraan di sekolah. Kesejahteraan di sekolah dapat memengaruhi siswa untuk lebih mudah mempelajari serta memahami informasi secara efektif dan menunjukkan perilaku sosial yang sehat dan memuaskan. Selain itu, siswa yang merasa terhubung dengan sekolahnya menunjukkan performa akademik yang lebih baik (Bücker dkk., 2018; Heffner \& Antaramian, 2016). Oleh karena itu siswa perlu merasa sejahtera ketika berada di sekolah (Kurniasih, 2017).

Kesejahteraan sering disebut dengan istilah well-being, yang secara umum diartikan sebagai kebahagiaan dan keadaan yang nyaman. Penjelasan mengenai wellbeing dapat dijelaskan melalui pendekatan hedonic, yang memfokuskan well-being pada kebahagiaan subjektif, berfokus pada pengalaman yang lebih banyak memberi pengaruh positif; serta tingkat kepuasaan yang tinggi terhadap kehidupan seseorang. Konsep subjective well-being menggunakan pendekatan ini (Deci \& Ryan, 2008). Lebih jauh subjective wellbeing adalah sejauhmana seorang individu melakukan evaluasi terhadap kehidupannya, refleksi kognitif dari domain hidupnya, termasuk emosi dan mood-nya pada kehidupan tersebut (Diener dkk., 2017). Subjective well-being yang dimaksud pada penelitian ini berfokus pada pendekatan domain khusus dalam kehidupan, yaitu domain sekolah yang disebut sebagai kesejahteraan subjektif di sekolah.

Kesejahteraan subjektif di sekolah yang dikonseptualisasikan oleh Tian (2008) merupakan eksplorasi dari konsep subjective well-being yang diungkapkan oleh Diener dkk. (2017) yang difokuskan pada domain sekolah. Menurut Tian (2008), subjective well-being seseorang atau anak tentu akan berbeda pada tempat atau domain yang berbeda, salah satunya kesejahteraan subjektif di sekolah. Kesejahteraan subjektif di sekolah merupakan evaluasi atau penilaian siswa secara subjektif dan emosional mengenai pengalaman kehidupan mereka di sekolah. Kesejahteraan subjektif di sekolah merupakan indikator yang mencerminkan tidak hanya kualitas hidup siswa remaja tetapi juga kualitas pendidikan di sekolah (Tian dkk., 2014). Konseptualisasi model kesejahteraan subjektif di sekolah meliputi komponen kognitif, yaitu school satisfaction dan komponen afektif, yaitu affect in school (Liu dkk., 2015; Tian, 2008; Tian dkk., 2014). School satisfaction merupakan komponen pertama dari konstruk ini. Komponen ini mengukur evaluasi kognitif dengan menggunakan standar internal siswa terhadap lingkungan sekolah sehari-hari. Sementara itu, komponen kedua yaitu afektif mengukur seberapa sering siswa mengalami dua pengalaman emosi yaitu emosi positif dan negatif di sekolah (Liu dkk., 2015; Tian, 2008; Tian dkk., 2014). Pada penelitian ini, sekolah yang dimaksud adalah sekolah berbasis pondok pesantren modern.

Salah satu variabel yang dapat diidentifikasi sebagai prediktor kesejahteraan subjektif di sekolah adalah hubungan yang suportif dari jaringan sosial seperti keluarga, guru, dan teman sekelas di sekolah atau biasa disebut dengan dukungan sosial (Ammar dkk., 2013; Awang dkk., 2014; Cutrona \& Russell, 1990; Siedlecki dkk., 2014). Secara umum 
dukungan sosial mengacu pada ketersediaan sumber daya yang dapat diberikan lingkungan kepada seorang individu untuk membantu mereka mengatasi masalah (Wills dkk., 2014). Barrera (1986) mengungkapkan ada tiga konsep dukungan sosial yaitu keterikatan sosial, persepsi dukungan sosial, dan dukungan sosial aktual. Namun demikian, persepsi dukungan sosial adalah faktor prediksi terhadap well-being yang lebih baik daripada dukungan aktual yang sudah diberikan (Siedlecki dkk., 2014).

Salah satu model yang menggambarkan dukungan sosial adalah model Weiss (1974) tentang 'Social Provisions' yang juga menjadi dasar dari pengembangan teori dan pengukuran dukungan sosial. Model ini termasuk ke dalam jenis konsep persepsi dukungan sosial (Gottlieb \& Bergen, 2010). Secara spesifik terdapat enam fungsi sosial yang berbeda atau "provisions (ketersediaan)" yang dapat diperoleh dari hubungan dengan orang lain. Keenam fungsi sosial tersebut diperlukan individu untuk merasa didukung secara memadai dan untuk menghindari kesepian. Enam fungsi sosial tersebut adalah tersedianya saran dan informasi (guidance), jaminan bahwa orang lain dapat diandalkan untuk memberikan bantuan nyata (reliable alliance), pengakuan atau penghargaan terhadap kemampuan dan kualitas individu (reassurance of worth), pengekspresian kasih sayang dan cinta yang diterima individu (attachment), kesamaan minat dan perhatian serta rasa memiliki dalam suatu kelompok (social integration), dan perasaan individu bahwa ia dibutuhkan oleh orang lain (opportunity to provide nurturance).

Banyak penelitian telah dilakukan untuk melihat kaitan antara dukungan sosial dengan subjective well-being pada setting yang berbeda. Namun demikian temuan penelitian tersebut masih cenderung belum konsisten dan berbeda satu sama lain. Beberapa penelitian menemukan bahwa dukungan sosial memiliki pengaruh positif terhadap kesejahteraan subjektif siswa. Secara spesifik dukungan tersebut berasal dari orang tua (Alcantara dkk., 2017; Awang dkk., 2014) dan teman serta guru di sekolah (Liu dkk., 2015; Tian dkk., 2015). Dukungan sosial dapat memengaruhi subjective well-being karena menawarkan emosi positif, rasa harga diri, dan prediktabilitas dalam kehidupan; juga berfungsi sebagai buffer stress dengan memperkuat self-esteem, self-efficacy, dan perilaku pemecahan masalah (Cutrona \& Russell, 1987; Liu dkk., 2015). Selain itu, dukungan sosial dapat meningkatkan kepuasan yang merupakan komponen dari subjective well-being. Proses yang terjadi ketika seseorang mengevaluasi lingkungannya, ia merasa terdapat orang lain yang menjadi tempat ia bergantung atau dapat dipercaya ketika dibutuhkan (Siedlecki dkk., 2014). Lebih jauh ketiadaan dukungan sosial dari orang tua akan cenderung mengakibatkan perilaku yang buruk pada diri anak seperti penggunaan obat terlarang (Wills dkk., 2014) dan merokok (Wills dkk., 2017).

Beberapa penelitian lain menunjukkan hasil yang bertolak belakang. Dukungan sosial yang diberikan tidak memberikan dampak terhadap well-being individu (Uchino, 2009). Secara lebih spesifik, Alcantara dkk. (2017) menemukan bahwa dukungan sosial yang diterima dari keluarga adalah prediktor signifikan subjective well-being, namun persepsi dukungan sosial yang diterima dari sahabat dekat dan dukungan sosial dari teman bukanlah prediktor subjective well-being. Tidak adanya kaitan antara kedua variabel tersebut dapat terjadi ketika individu menerima lebih banyak dukungan daripada yang mereka butuhkan (Melrose dkk., 2015). Selain itu, Siedlecki dkk. (2014) menjelaskan bahwa besarnya asosiasi bergantung pada aspek dari konsep persepsi dukungan sosial yang diteliti.

Dalam konteks siswa yang tinggal di pondok pesantren yang berada pada masa remaja, orang tua sebagai komponen 

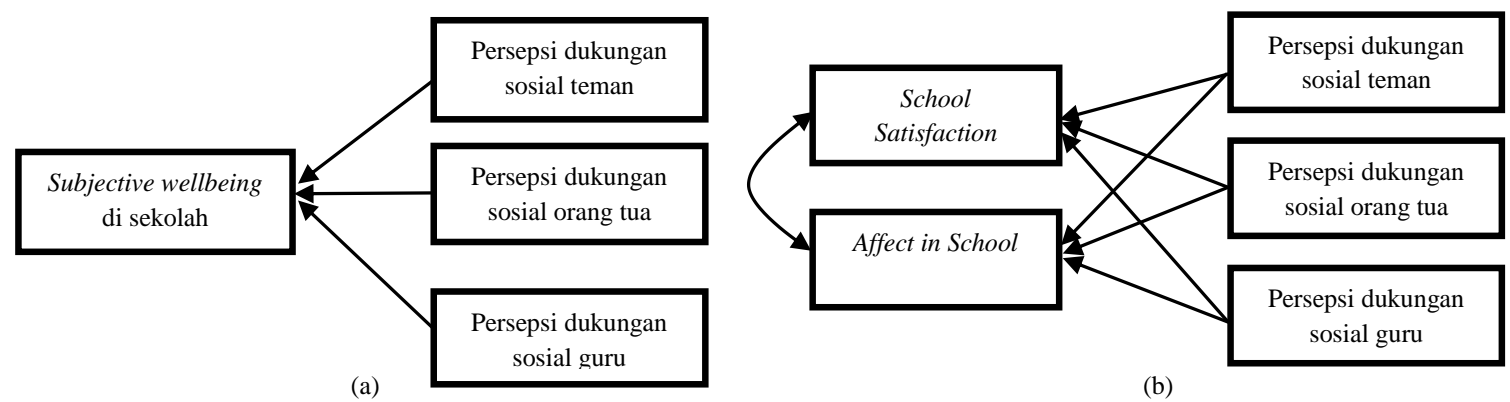

Gambar 1. Model analisa jalur pengujian hipotesis

dukungan sosial memiliki peran penting dalam memantau perkembangan anak. Pemantauan termasuk mengawasi pilihan social setting, kegiatan, teman, dan akademik mereka. Kurang memadainya pantauan dari orang tua dapat menjadi faktor yang paling mungkin terkait dengan kenakalan remaja (Santrock, 2011; Wills dkk., 2014, 2017). Namun siswa yang bersekolah di pondok pesantren akan jauh dari orang tua, siswa tinggal selama 24 jam di pondok pesantren, sehingga interaksi antara orang tua dan siswa yang bersekolah di pondok pesantren modern lebih terbatas jika dibandingkan interaksi siswa dengan teman dan guru di sekolah. Waktu bertemu dengan orang tua hanya terjadi saat pulang ke rumah masing-masing pada akhir semester atau jika mereka dijenguk. Sementara itu, Newman dan Newman (2017) menjelaskan bahwa meskipun pada masa remaja awal merupakan waktu dimana individu memperluas hubungan mereka dengan situasi dan peran yang baru, tetapi orang tua akan terus menjadi jaminan sumber daya dan dukungan yang penting bagi mereka. Hal ini menunjukkan dukungan dari teman, guru, dan orang tua akan berpengaruh terhadap kehidupan remaja di sekolah.

Berdasarkan ringkasan dari penelitianpenelitian di atas, peneliti ingin mengetahui kaitan antara persepsi dukungan sosial yang berasal dari teman, guru, dan orang tua dengan kesejahteraan subjektif di sekolah. Persepsi dukungan sosial siswa dalam studi ini dapat diketahui melalui penilaian siswa mengenai provisions (ketersediaan dukungan) dari interaksi mereka dengan orang lain, yaitu interaksi siswa dengan teman, guru, dan orang tua. Beberapa penelitian menyatakan bahwa subjective well-being merupakan satu konstruk yang utuh (Gülaçt1, 2010; Stallman dkk., 2017; Tian dkk., 2015), sementara yang lain melihat sebagai konstruk yang memiliki dua dimensi yaitu satisfaction dan affect (Liu dkk., 2015; Ammar dkk., 2013; Tian Liu dkk., 2013). Dengan demikian studi ini memiliki dua tujuan sebagaimana direpresentasikan pada gambar 1 yaitu: (1) melihat peran dari persepsi dukungan sosial teman, guru, dan orang tua terhadap kesejahteraan subjektif siswa di sekolah; (2) menguji peran dari persepsi dukungan sosial teman, guru, dan orang tua terhadap dua dimensi dalam kesejahteraan subjektif di sekolah yaitu school satisfaction dan affect in school.

\section{Metode Penelitian}

Penelitian ini merupakan studi kuantitatif korelasional dengan pendekatan analisa jalur. Secara spesifik, persepsi dukungan sosial diuji perannya terhadap kesejahteraan subjektif di sekolah. Pengambilan data berlokasi di salah satu Pondok Pesantren Modern di Jawa Barat. Pemilihan responden menggunakan metode stratified random sampling. Responden penelitian ini adalah siswa kelas 7 dan 8 SMP. Jumlah partisipan sebanyak 264 orang, terdiri dari $76 \%$ perempuan dan $24 \%$ laki-laki. 


\section{Instrumen Pengukuran}

Pengukuran persepsi dukungan sosial menggunakan kuesioner Social Provisions Scale yang disusun oleh Cutrona dan Russell (1987) berdasarkan teori yang dikemukakan oleh Weiss (1974), yang telah diadaptasi dalam bahasa Indonesia, dan dilakukan uji coba yang menghasilkan instrumen yang reliabel dan valid. Skala tersebut terdiri dari 24 item yang menggambarkan enam dimensi, yaitu guidance, reliable alliance, attachment, reassurance of worth, social integration, dan opportunity to provide nurturance. Masing-masing dimensi terdiri dari empat item (dua item positif dan dua item negatif). Salah satu contoh item "Saya berada di dalam suatu kelompok dimana anggotanya memiliki pikiran yang sama dengan saya tentang berbagai hal". Pilihan jawaban terdiri dari empat pilihan, menggunakan skala Likert dengan rentang pilihan 1 yang menggambarkan sangat tidak setuju hingga 4 yang berarti sangat setuju. Reliabilitas skala ini memiliki koefisien cronbach's alpha .875 untuk persepsi dukungan teman; .764 untuk persepsi dukungan sosial teman; dan .865 untuk persepsi dukungan guru.

Variabel kesejahteraan subjektif di sekolah diukur menggunakan Brief Adolescents' Subjective Well-Being in School Scale (BASWBSS) yang disusun oleh Tian dkk. (2014) dan sudah diadaptasi oleh Wijayanti (2018) dengan hasil yang menunjukkan bahwa alat ukur valid dan reliabel. Skala tersebut terdiri dari 8 item yang menggambarkan dua subskala yaitu school satisfaction dengan jumlah enam item, dan affect in school yang terdiri dari dua item masing-masing mewakili positive affect dan negative affect di sekolah. Salah satu contoh item "Saya memiliki hubungan yang baik dengan para guru". Pilihan jawaban subskala school satisfaction terdiri dari enam pilihan berskala likert mulai dari 1 hingga 6 dengan arti secara berurutan mulai dari "sangat tidak setuju" hingga "sangat setuju". Sedangkan pilihan subskala affect in school terdiri dari enam pilihan skala likert "dari tidak pernah" sampai dengan "selalu". Koefisien cronbach's alpha pada skala ini adalah .769 .

Pengumpulan bukti validitas dilakukan dengan menggunakan struktur internal melalui metode analisis faktor konfirmasi. Analisa ini menggunakan program $\mathrm{R}$ studio dengan paket Lavaan versi 0.6-3. Untuk persepsi dukungan sosial menggunakan model satu faktor dengan enam variabel observasi dari nilai total dimensi guidance, reliable alliance, attachment, reassurance of worth, social integration, dan opportunity to provide nurturance. Sementara itu untuk kesejahteraan subjektif di sekolah, uji model dua faktor (school satisfaction dan affect in school) dengan delapan variabel observasi dari delapan item yang digunakan. Beberapa uji kecocokan model yang digunakan yaitu Root Mean Square Error of Approximation (RMSEA), Comparative Fit Index (CFI) dan Standardized Root Mean Square Residual (SRMR). Standard kecocokan model adalah nilai RMSEA < .08, CFI > .90 dan SRMR < .08 (Kline, 2015). Berdasarkan analisa yang dilakukan didapatkan nilai uji kecocokan sebagaimana disajikan pada tabel 1. Dapat disimpulkan bahwa keempat instrumen pengukuran memenuhi kriteria kecocokan uji model sehingga memiliki konstruk validitas yang baik.

Tabel 1

Hasil Uji Validitas setiap Variabel

\begin{tabular}{lccrrr}
\hline Variabel & $\chi 2$ & p value & RMSEA & CFI & SRMR \\
\hline Persepsi dukungan sosial guru & $(\mathrm{df}=7)=10.492$ & .162 & .043 & .994 & .025 \\
Persepsi dukungan sosial teman & $(\mathrm{df}=9)=14.127$ & .116 & .047 & .991 & .025 \\
Persepsi dukungan sosial orang tua & $(\mathrm{df}=9)=22.994$ & .006 & .077 & .948 & .049 \\
Kesejahteraan subjektif di sekolah & $(\mathrm{df}=17)=22.970$ & .158 & .036 & .998 & .035 \\
\hline
\end{tabular}




\section{Prosedur}

Beberapa prosedur dilakukan dalam pengambilan data. Pertama, permohonan izin dilakukan kepada pihak sekolah. Kedua, setelah mendapatkan izin, partisipan mengisi informed consent sebagai tanda kesediaan dalam penelitian ini. Hanya peserta yang menyatakan bersedia yang mengikuti pengambilan data. Ketiga, kuesioner tetap dalam keadaan anonim agar menghindari tekanan kepada peserta dalam mengerjakan. Peserta pun dapat memilih apakah akan mengumpulkan secara lengkap ataupun tidak lengkap. Pengambilan data dilakukan secara klasikal yang terdiri 20-30 peserta dengan menggunakan kuesioner tertulis yang dipandu oleh seorang instruktur.

\section{Analisa}

Analisa statistika deskriptif dilakukan untuk melihat rata-rata dan sebaran dari setiap variabel. Korelasi Pearson digunakan untuk melihat kaitan antara variabelvariabel yang diujikan. Guna melihat peran dari persepsi dukungan sosial teman, guru, dan orang tua terhadap kesejahteraan subjektif di sekolah dan tiap dimensinya yaitu school satisfaction dan affect in school digunakan multiple regression dan analisa jalur. Kedua analisa tersebut menggunakan program $\mathrm{R}$ studio dengan paket 'apaTables' versi 2.0.5 dan Lavaan versi $0.6-3$.

\section{Hasil Penelitian dan Pembahasan}

Hasil analisis deskriptif dan korelasi antara variabel dilaporkan pada tabel 2 . Pada kedua aspek kesejahteraan subjektif di sekolah, nilai school satisfaction siswa lebih tinggi dibandingkan dengan affect in school. Sementara itu, rata-rata paling besar pada variabel persepsi dukungan sosial adalah (1) persepsi dukungan sosial dari orang tua; (2) persepsi dukungan sosial dari teman; dan (3) persepsi dukungan sosial dari guru. Hasil pengujian multiple regression dan analisa jalur ditampilkan pada tabel 3. Hasil menunjukkan bahwa persepsi dukungan sosial dari teman $(\beta=.354, \quad p<.01)$ dan persepsi dukungan sosial dari guru $(\beta=.127, p<.01)$ berperan positif terhadap kesejahteraan subjektif di sekolah. Hasil menunjukkan bahwa semakin siswa mempersepsikan ia menerima dukungan sosial yang disediakan oleh teman dan guru, maka evaluasi siswa terhadap kehidupan di sekolahnya semakin positif atau siswa semakin merasa sejahtera di sekolah. Pada lain pihak, persepsi dukungan sosial dari orang tua tidak berperan secara signifikan terhadap kesejahteraan subjektif di sekolah $(\beta=-.021$, $\mathrm{p}=.708$ ). Hal ini menunjukkan bahwa semakin tinggi siswa mempersepsikan ia menerima dukungan sosial yang disediakan oleh orang tua belum tentu meningkat pula kesejahteraannya di sekolah. Ketiga persepsi dukungan sosial tersebut menjelaskan variasi tingkat kesejahteraan subjektif di sekolah sebesar $14.2 \%$.

Pada penelitian ini, dilihat pula peranan persepsi dukungan sosial dari teman, orang tua, dan guru terhadap setiap dimensi dari kesejahteraan subjektif di sekolah, yaitu school satisfaction dan affect in school. Tabel 3 menunjukkan hasil bahwa persepsi dukungan sosial teman berperan terhadap peningkatan school satisfaction $(\beta=.186, \mathrm{p}<.01)$ dan affect in

Tabel 2

Rata-rata, Standar Deviasi, dan Matrik Korelasi setiap Variabel

\begin{tabular}{|c|c|c|c|c|c|c|c|}
\hline Variabel & $M$ & $S D$ & 1 & 2 & 3 & 4 & 5 \\
\hline 1. Kesejahteraan subjektif di sekolah & 4.03 & .80 & & & & & \\
\hline 2. School satisfaction & 4.38 & .87 & $.77 * *$ & & & & \\
\hline 3. Affect in school & 3.68 & .09 & $.86^{* *}$ & $.33 * *$ & & & \\
\hline 4. Persepsi dukungan sosial teman & 3.03 & .38 & $.40 * *$ & $.26 * *$ & $.38 * *$ & & \\
\hline 5. Persepsi dukungan sosial orang tua & 3.50 & .30 & $.15^{*}$ & .04 & $.18 * *$ & $.34 * *$ & \\
\hline 6. Persepsi dukungan sosial guru & 2.90 & .39 & $.28 * *$ & $.29 * *$ & $.17 * *$ & $.45 * *$ & $.39 * *$ \\
\hline
\end{tabular}


school $(\beta=.253, \mathrm{p}<.01)$. Artinya, semakin tinggi siswa mempersepsikan ia menerima dukungan sosial yang disediakan oleh teman, maka semakin tinggi pula kepuasan siswa di sekolah, semakin tinggi perasaan positifnya, dan semakin rendah perasaan negatifnya. Sementara itu persepsi dukungan sosial dari guru berhubungan signifikan dengan school satisfaction $(\beta=.253, \mathrm{p}<.01)$ tetapi tidak dengan affect in school $(\beta=-.019, \quad \mathrm{p}=.744), \quad$ artinya semakin tinggi siswa mempersepsikan ia menerima dukungan sosial yang disediakan oleh guru, maka semakin tinggi pula kepuasan siswa di sekolah, tetapi belum tentu semakin tinggi pula perasaan positif di sekolah. Kondisi yang menarik terjadi pada peranan persepsi dukungan sosial dari orang tua terhadap school satisfaction $(\beta=-$ $.122, \mathrm{p}<.01)$. Hasil menunjukkan bahwa persepsi dukungan sosial dari orang tua berperan negatif, meskipun peranannya rendah.

Peranan yang positif dari persepsi dukungan sosial teman terhadap kesejahteraan subjektif di sekolah menunjukkan bahwa jika siswa mempersepsikan bahwa temannya menyediakan dukungan sosial saat mereka membutuhkan, maka evaluasi siswa terhadap kehidupannya di sekolah akan menjadi lebih positif atau kesejahteraan siswa di sekolah meningkat. Temuan ini juga melengkapi penelitian sebelumnya, dimana dukungan sosial dari teman sekelas memiliki implikasi penting bagi kesejahteraan subjektif siswa di sekolah (Jiang dkk., 2013; Liu dkk., 2015; Tian dkk., 2013). Interaksi sosial yang baik antar teman merupakan salah satu hal yang paling berkontribusi pada well-being remaja di sekolah (Alcantara dkk., 2017; Awang dkk., 2014; Wijayanti, 2018). Dukungan teman sekelas secara signifikan cenderung memprediksi kesejahteraan subjektif siswa, terutama selama masa remaja, periode kritis dimana kebutuhan siswa untuk dukungan dari teman meningkat (Liu dkk., 2015). Hal ini disebabkan karena siswa merasa yakin bahwa teman sebaya muncul sebagai pendukung untuk penyesuaian akademik, sosial, dan emosional sementara ketiadaan teman akan menyulitkannya dalam memenuhi tuntutan dari pembelajaran (Awang dkk., 2014).

Responden penelitian ini seluruhnya adalah siswa sekolah menengah pertama. Pada masa yang dianggap sebagai periode kritis ini, terjadi peningkatan kebutuhan akan persahabatan dengan teman sebaya, sehingga dukungan teman sekelas mulai memainkan peran yang semakin signifikan dalam kehidupan siswa (Awang dkk., 2014; Liu dkk., 2015). Siswa kelas tujuh dan delapan sedang berada pada masa remaja awal. Salah satu tugas perkembangan masa remaja awal adalah membership in the peer groups. Peer group membership terdiri dari pengembangan ikatan pertemanan yang erat diantara usia yang sama dan proses penilaian pribadi tentang teman yang akan membuat mereka puas dengan pertemanan tersebut (Newman \& Newman, 2017).

Secara spesifik ditemukan pula bahwa persepsi dukungan sosial teman berperan signifikan terhadap dua dimensi lain yaitu school satisfaction dan affect in school. Hasil tersebut sejalan dengan penelitian sebelumnya yang mengungkapkan bahwa pada masa remaja hubungan dengan teman mulai memberikan dampak yang lebih besar pada kepuasan hidup siswa (Jenkins dkk., 2013; Matsuda dkk., 2014). Selain itu penelitian sebelumnya menunjukkan bahwa dukungan teman sebaya secara signifikan terkait dengan positive affect dan negative affect (Liu dkk., 2015). Jadi, interaksi dengan teman dapat memengaruhi perasaan senang atau sedih yang siswa rasakan di sekolah, karena pada siswa yang berusia remaja cenderung mengembangkan lebih banyak aktivitas bersama dengan temantemannya (Liu dkk., 2015); pada masa ini, remaja mulai mengalihkan dukungan yang berasal dari orang tua kepada temannya di sekolah (Sheets Jr \& Mohr, 2009). 
Ikatan pertemanan yang erat, penuh perhatian, adanya rasa memiliki dan penilaian yang baik terhadap temannya membuat siswa pondok pesantren modern puas dengan pertemanannya di sekolah; hal tersebut akan memengaruhi perasaan mereka di sekolah. Ikatan pertemanan ini biasa disebut dengan konsep attachment dan social integration yang termasuk ke dalam dimensi dari persepsi dukungan sosial. Attachment berkaitan dengan kedekatan, perhatian, kasih sayang, dan cinta; sedangkan social integration berkaitan dengan persamaan kesukaan, atensi, serta rasa memiliki terhadap satu kelompok, dalam hal ini dengan teman (Cutrona \& Russell, 1987; Cutrona dkk., 1994). Siswa di pondok pesantren modern, tinggal menetap di lingkungan sekolahnya, sehingga lebih sering bertemu, menghabiskan waktu bersama dengan teman, dan melakukan berbagai aktivitas bersama dengan teman sekolahnya, seperti belajar, kegiatan berkelompok, dan berkumpul. Hubungan pertemanan antara siswa dengan rekannya di lingkungan pondok pesantren modern dapat memberikan pengaruh pada perasaan mereka di sekolah. Ketika siswa merasa memiliki pihak lain saat mereka membutuhkan dan kebutuhan tersebut terpenuhi maka hal tersebut dapat meningkatkan kesejahteraan subjektif dari siswa (Melrose dkk., 2015; Siedlecki dkk., 2014).

Temuan lain menunjukkan bahwa setelah teman, gurulah yang berperan dalam peningkatan kesejahteraan subjektif di sekolah pada aspek school satisfaction. Dengan kata lain, semakin positif persepsi dukungan sosial guru maka akan semakin positif pula kepuasannya di sekolah. Temuan penelitian ini serupa dengan penelitian sebelumnya yang menyatakan bahwa pada remaja awal, dukungan sosial dari guru secara signifikan memprediksi school satisfaction (Tennant dkk., 2015; Tian dkk., 2013). Hal tersebut karena dukungan guru pada satu waktu tidak hanya memprediksi kepuasan sekolah pada saat itu saja, tetapi juga memperkirakan kepuasan sekolah lima bulan kemudian (Jiang dkk., 2013; Tian dkk., 2013). Lebih jauh dijelaskan bahwa dukungan sosial dari guru membantu siswa untuk memahami permasalahan yang dihadapinya sehingga dapat menurunkan tingkat kesulitan dari siswa di sekolah (Tennant dkk., 2015). Selain itu, dukungan dari guru ini akan membantu siswa dalam beradaptasi dengan lingkungan sehingga siswa dapat belajar secara mandiri dalam proses belajar (Kiefer dkk., 2015). Ketika siswa dapat memberi evaluasi positif terhadap lingkungannya

Tabel 3

Koefisien Regresi dari Variabel Persepsi Dukungan Sosial terhadap Kesejahteraan Subjektif di Sekolah

\begin{tabular}{lllcccc}
\hline \multicolumn{1}{c}{ Variabel Dependen } & $\mathrm{R}^{2}$ & $\begin{array}{c}\text { Variabel } \\
\text { Independen }\end{array}$ & Estimate & SE & $\mathrm{Z}$ & Beta \\
\hline $\begin{array}{l}\text { Kesejahteraan subjektif } \\
\text { di sekolah }\end{array}$ & \multirow{2}{*}{0.142} & PDS Teman & .732 & .118 & 6.215 & $.354^{* *}$ \\
& & PDS Orang tua & -.056 & .150 & -0.375 & -.021 \\
& & PDS Guru & .254 & .114 & 2.234 & $.127^{* *}$ \\
School satisfaction & \multirow{2}{*}{0.114} & PDS Teman & .426 & .133 & 3.216 & $.186^{* *}$ \\
& & PDS Orang tua & -.354 & .168 & -2.102 & $-.122^{*}$ \\
Affect in school & & PDS Guru & .559 & .128 & 4.367 & $.253^{* *}$ \\
& \multirow{2}{*}{0.139} & PDS Teman & 1.038 & .162 & 6.407 & $.366^{*}$ \\
& & PDS Orang tua & .242 & .206 & 1.177 & .067 \\
\hline
\end{tabular}

*signifikan pada $\mathrm{p}<.05$ dan $* * \mathrm{p}<.01, \mathrm{PDS}=$ Persepsi Dukungan Sosial 
maka hal tersebut menggambarkan subjective well-being dan satisfaction yang positif (Diener dkk., 2017; Siedlecki dkk., 2014; Stallman dkk., 2017).

Sementara itu pada aspek affect in school, guru belum memiliki peran yang signifikan. Umumnya siswa merasa tidak bebas menceritakan masalah-masalah nonakademik kepada guru (Liu dkk., 2015). Keadaan tersebut juga dijelaskan dalam penelitian lain bahwa pada siswa sekolah menengah, variabel dukungan guru tidak secara signifikan memprediksi affect in school. Dukungan guru hanya secara signifikan terkait dengan affect in school untuk siswa sekolah dasar. Dukungan guru memainkan peran yang lebih besar dalam keberhasilan dan perilaku akademik bagi siswa (Roorda dkk., 2011; Liu dkk., 2015).

Banyak penelitian sebelumnya menunjukkan bahwa dukungan sosial dari orang tua dan guru berkorelasi positif dengan subjective well-being (Alcantara dkk., 2017; Tian dkk., 2013; Wang dkk., 2018). Namun demikian, hasil dari penelitian ini tidak mendukung temuan dari studi sebelumnya. Perbedaan temuan ini dapat disebabkan karena perbedaan latar belakang sekolah dengan penelitian sebelumnya; pada penelitian ini siswa bersekolah di pondok pesantren modern dan harus tinggal di asrama dengan peraturan-peraturan yang sudah ditentukan dan sangat berbeda dengan sekolah umum; orang tua tidak hadir secara nyata pada keseharian siswa. Hal ini senada dengan yang dijelaskan oleh Alcantara dkk. (2017) bahwa waktu yang digunakan bersama dengan orang tua akan memberikan dampak langsung terhadap subjective wellbeing; sehingga ketika waktu berkurang maka kehadirannya dialihkan kepada pihak lain dalam hal ini teman dan guru. Tidak adanya hubungan antara persepsi dukungan orang tua dengan kesejahteraan subjektif di sekolah dan setiap dimensinya juga dapat terjadi karena adanya perbedaan kontribusi dukungan orang tua terhadap well-being dalam kehidupan umum secara global dengan well-being dalam domain spesifik, khususnya domain sekolah. Dalam sebuah studi di Amerika Serikat, dukungan orang tua muncul sebagai prediktor terkuat kepuasan hidup global remaja. Temuan bahwa orang tua tidak menjadi prediktor kuat kesejahteraan subjektif di sekolah menunjukkan bahwa mungkin ada perbedaan dalam kontribusi dukungan orang tua pada kesejahteraan sekolah versus kesejahteraan global, yang juga perlu studi lebih lanjut (Tian dkk., 2013).

Pada penelitian ini, nilai rata-rata skor total persepsi dukungan sosial orang tua lebih tinggi daripada nilai rata-rata persepsi dukungan sosial teman dan guru. Hal tersebut menunjukkan bahwa siswa merasakan adanya dukungan sosial yang tersedia paling tinggi dari proses interaksi mereka dengan orang tua, kemudian teman, dan terakhir dari guru. Jika melihat tahap perkembangan subjek penelitian ini, siswa sedang berada pada masa remaja (12-14 tahun), dimana teman menjadi semakin penting sebagai sumber dukungan. Namun remaja tetap berpendapat bahwa anggota keluarga adalah orang yang paling sentral dalam kehidupan mereka; orang yang dinilai paling dekat dengan remaja dan yang paling mencintai mereka adalah keluarga (Newman \& Newman, 2017). Hal tersebut dijelaskan dalam penelitian mengenai persepsi dukungan sosial, bahwa persahabatan dan hubungan romantis secara umum relatif baru, dibandingkan relasi dengan orang tua. Dengan demikian, efek dukungan dari sumber tersebut mungkin merupakan hasil dari interaksi yang terjalin dalam waktu dekat. Sebaliknya, efek dukungan sosial dari orang tua mungkin merupakan kombinasi dari efek perkembangan interaksi dari waktu ke waktu dengan penerimaan dan pengasuhan yang tersedia dari orang tua, ditambah pengaruh dari interaksi yang terjalin dalam waktu dekat (Cutrona dkk., 1994).

Penelitian ini berupaya memberikan kontribusi terhadap literatur yang berkaitan dengan kesejahteraan subjektif siswa di 
sekolah yang berbentuk pesantren modern. Temuan ini dapat menjadi masukan kepada pihak pesantren untuk mengembangkan lingkungan pertemanan yang baik diantara siswa di sekolah sehingga dapat memberikan dukungan terhadap pengembangan kesejahteraan siswa di sekolah. Selain daripada itu, guru diharapkan dapat memperhatikan hubungan baik dengan siswa karena dukungan dari guru akan meningkatkan kepuasan siswa di sekolah.

Penelitian ini memiliki beberapa limitasi yang dapat dikembangkan untuk penelitian selanjutnya. Pertama, model dalam penelitian ini hanya sebatas pada variabel kesejahteraan subjektif di sekolah sebagai hasil akhirnya; pada penelitian selanjutnya dapat diperluas dengan menambahkan variabel seperti prestasi akademik, penyesuaian diri, dan selfefficacy. Kedua, melihat pengaruh yang lemah dan bahkan bersifat negatif dari variabel dukungan sosial dari orang tua, perlu ditelaah lebih jauh mengenai pola komunikasi dan relasi siswa yang tinggal di pesantren dengan orang tuanya. Ketiga, penelitian ini hanya dilakukan pada satu pesantren, dengan demikian penambahan jumlah responden dan jumlah pesantren juga diharapkan dapat meningkatkan generalisasi hasil penelitian.

\section{Simpulan}

Penelitian ini memberikan hasil bahwa persepsi dukungan sosial dari teman berperan positif terhadap peningkatan kesejahteraan subjektif di sekolah. Secara lebih spesifik persepsi dukungan ini juga memengaruhi kepuasan dan perasaan siswa di sekolah, sehingga lingkungan pertemanan yang baik diantara siswa di sekolah cukup penting karena dapat memberikan peran signifikan dalam pengembangan kesejahteraan siswa di sekolah. Penelitian ini menemukan bahwa siswa masih memersepsikan dukungan yang paling rendah diberikan oleh guru, sedangkan dukungan dari guru merupakan modal yang penting untuk sekolah tipe pesantren karena interaksi cukup banyak dilakukan antara guru dan siswa, melebihi interaksi siswa dengan orang tua. Dengan demikian guru di pesantren disarankan untuk tidak hanya berperan sebagai pengajar, namun perlu melakukan upaya untuk lebih dekat dengan siswa dan meningkatkan perhatian terhadap para siswa.

\section{Daftar Pustaka}

Alcantara, S. C., González-Carrasco, M., Montserrat, C., Viñas, F., Casas, F., \& Abreu, D. P. (2017). Peer violence in the school environment and Its relationship with subjective well-being and perceived social support among children and adolescents in Northeastern Brazil. Journal of Happiness Studies, 18(5), 1507-1532. https://doi.org/10.1007/s10902-0169786-1

Ammar, D., Nauffal, D., \& Sbeity, R. (2013). The role of perceived social support in predicting subjective wellbeing in Lebanese college students Lübnanlı üniversite öğrencilerinde, algilanan sosyal desteğin öznel iyi oluş üzerindeki yordayıc1 rolü. The Journal of Happiness \& Well-Being, 1(2), 121134.

Arsita, M., Nurhadi, \& Budiati, A. C. (2016). Rasionalitas pilihan orang tua terhadap pesantren sebagai lembaga pendidikan remaja awal. Sosialitas; Jurnal Ilmiah Pend. Sos Ant, 5(2).

Awang, M. M., Kutty, F. M., \& Ahmad, A. R. (2014). Perceived social support and well being: First-year student experience in university. International Education Studies, 7(13), 261-270.

Azizah, A., \& Hidayati, F. (2015). Penyesuaian sosial dan school wellbeing: Studi pada siswa pondok pesantren yang bersekolah di MBI Amanatul Ummah Pacet Mojokerto. 
Jurnal Empati, 4(4), 84-89.

Barrera Jr, M. (1986). Distinctions between social support concepts, measures, and models. American Journal of Community Psychology, 14(4), 413445.

Bücker, S., Nuraydin, S., Simonsmeier, B. A., Schneider, M., \& Luhmann, M. (2018). Subjective well-being and academic achievement: A metaanalysis. Journal of Research in Personality, 74, 83-94.

Cutrona, C. E., Cole, V., Colangelo, N., Assouline, S. G., \& Russell, D. W. (1994). Perceived parental social support and academic achievement: An attachment theory perspective. Journal of Personality and Social Psychology, 66(2), 369.

Cutrona, C. E., \& Russell, D. W. (1987). The provisions of social relationships and adaptation to stress. Advances in Personal Relationships, 1(1), 37-67.

Cutrona, C. E., \& Russell, D. W. (1990). Type of social support and specific stress: Toward a theory of optimal matching. Dalam B. R. Sarason, I. G. Sarason, \& G. R. Pierce (Eds.), Wiley series on personality processes. Social support: An interactional view (p. 319 366). John Wiley \& Sons.

Deci, E. L., \& Ryan, R. M. (2008). Hedonia, eudaimonia, and well-being: An introduction. Journal of Happiness Studies, 9(1), 1-11.

Diener, E., Pressman, S. D., Hunter, J., \& Delgadillo- Chase, D. (2017). If, why, and when subjective well- being influences health, and future needed research. Applied Psychology: Health and Well-Being, 9(2), 133-167.

Gottlieb, B. H., \& Bergen, A. E. (2010). Social support concepts and measures. Journal of Psychosomatic Research, 69(5), 511-520.

Gülaçtı, F. (2010). The effect of perceived social support on subjective wellbeing. Procedia-Social and Behavioral Sciences, 2(2), 3844-3849.
Heffner, A. L., \& Antaramian, S. P. (2016). The role of life satisfaction in predicting student engagement and achievement. Journal of Happiness Studies, 17(4), 1681-1701.

Irwandi, S., Ufatin, N., \& Sultoni, S. (2016). Peran sekolah dalam menumbuhkembangkan perilaku hidup sehat pada siswa sekolah dasar (studi multi situs di SD negeri 6 Mataram dan SD negeri 41 Mataram kota Mataram Nusa Tenggara Barat). Jurnal Pendidikan: Teori, Penelitian, dan Pengembangan, 1(3), 492-498.

Jenkins, S. R., Belanger, A., Connally, M. L., Boals, A., \& Durõn, K. M. (2013). First-generation undergraduate students' social support, depression, and life satisfaction. Journal of College Counseling, 16(2), 129-142. https://doi.org/10.1002/j.21611882.2013.00032.x

Jiang, X., Huebner, E. S., \& Siddall, J. (2013). A short-term longitudinal study of differential sources of school-related social support and adolescents' school satisfaction. Social Indicators Research, 114(3), 1073-1086.

Kiefer, S. M., Alley, K. M., \& Ellerbrock, C. R. (2015). Teacher and peer support for young adolescents' motivation, engagement, and school belonging. Rmle Online, 38(8), 1-18.

Kline, R. B. (2015). Principles and practice of structural equation modeling. Guilford publications.

Kurniasih, N. (2017). Kesejahteraan siswa di sekolah berasrama. (Tesis tidak diterbitkan).

Universitas

Muhammadiyah Surakarta.

Liu, W., Mei, J., Tian, L., \& Huebner, E. S. (2015). Age and gender differences in the relation between school-related social support and subjective wellbeing in school among students. Social Indicators Research, 125(3), 10651083. https://doi.org/10.1007/s11205015-0873-1

Matsuda, T., Tsuda, A., Kim, E., \& Deng, 
K. (2014). Association between perceived social support and subjective well-being among Japanese, Chinese, and Korean college students. Psychology, 05(06), 491-499. https://doi.org/10.4236/psych.2014.560 59

Melrose, K. L., Brown, G. D. A., \& Wood, A. M. (2015). When is received social support related to perceived support and well-being? When it is needed. Personality and Individual Differences, 77, 97-105.

Newman, B. M., \& Newman, P. R. (2017). Development through life: $A$ psychosocial approach. Cengage Learning.

Pritaningrum, M., \& Hendriani, W. (2013). Penyesuaian diri remaja yang tinggal di pondok pesantren modern Nurul Izzah Gresik pada tahun pertama. Jurnal Psikologi Kepribadian dan Sosial, 2(3), 134-143.

Roorda, D. L., Koomen, H. M. Y., Spilt, J. L., \& Oort, F. J. (2011). The influence of affective teacher-student relationships on students' school engagement and achievement: A metaanalytic approach. Review of Educational Research, 81(4), 493-529.

Santrock, J. W. (2011). Life-span development. Thirteenth Edition. McGraw-Hill.

Sheets Jr, R. L., \& Mohr, J. J. (2009). Perceived social support from friends and family and psychosocial functioning in bisexual young adult college students. Journal of Counseling Psychology, 56(1), 152163.

Siedlecki, K. L., Salthouse, T. A., Oishi, S., \& Jeswani, S. (2014). The relationship between social support and subjective well-being across age. Social Indicators Research, 117(2), 561-576.

Stallman, H. M., Ohan, J. L., \& Chiera, B. (2017). The role of social support, being present and self-kindness in university student well-being. British
Journal of Guidance and Counselling. https://doi.org/10.1080/03069885.2017 .1343458

Tennant, J. E., Demaray, M. K., Malecki, C. K., Terry, M. N., Clary, M., \& Elzinga, N. (2015). Students' ratings of teacher support and academic and social-emotional well-being. School Psychology Quarterly, 30(4), 494-512.

Tian, L. (2008). Developing scale for school well-being in adolescents. Psychological Development and Education, 24(3), 100-106.

Tian, L., Liu, B., Huang, S., \& Huebner, E. S. (2013). Perceived social support and school well-being among Chinese early and middle adolescents: The mediational role of self-esteem. Social Indicators Research, 113(3), 991-1008.

Tian, L., Wang, D., \& Huebner, E. S. (2014). Development and validation of the Brief Adolescents' Subjective Well-Being in School Scale (BASWBSS). Social Indicators Research, 120(2), 615-634. https://doi.org/10.1007/s11205-0140603-0

Tian, L., Zhao, J., \& Huebner, E. S. (2015). School-related social support and subjective well-being in school among adolescents: The role of self-system factors. Journal of Adolescence, 45, 138-148.

Uchino, B. N. (2009). Understanding the links between social support and physical health: A life-span perspective with emphasis on the separability of perceived and received support. Perspectives on Psychological Science, 4(3), 236-255.

Weiss, R. S. (1974). The provisions of social relationships'. Dalam Z. Rubin (eds) Doing unto others. Prentice-Hall.

Wijayanti, P. A. K. (2018). What is the most important learning environment dimensions to the adolescent subjective well-being in school?. Universitas Padjadjaran. (Dalam proses publikasi).

Wills, T. A., Forbes, M., \& Gibbons, F. X. 
Peranan Persepsi Dukungan Sosial terhadap Kesejahteraan Subjektif di Sekolah pada Siswa Pondok Pesantren Modern (Hasna Thohiroh, Langgersari Elsari Novianti, Whisnu Yudiana)

(2014). Parental and peer support: An analysis of their relations to adolescent substance use. Parenting and Teen Drug Use. New York: Oxford, 148-165.

Wills, T. A., Knight, R., Sargent, J. D., Gibbons, F. X., Pagano, I., \& Williams, R. J. (2017). Longitudinal study of e-cigarette use and onset of cigarette smoking among high school students in Hawaii. Tobacco Control, 26(1), 34-39. 
Psympathic, Jurnal Ilmiah Psikologi Desember 2019, Vol. 6, No. 2, Hal. : 131-144 